\title{
MONITORING, CORPORATE PERFORMANCE AND INSTITUTIONAL \\ DIRECTORS
}

\begin{abstract}
Our main objective is to study the effect of institutional directors on firm performance, distinguishing directors according to whether they maintain business relationships (pressuresensitive) or not (pressure-resistant). Our results show that in weak regulatory and low investor protection environments, institutional directors have a negative impact on corporate performance. Our evidence does not show that these two kinds of institutional directors behave differently. However, when we study the effect of board composition before and during the current financial crisis, the findings show that directors with no business relationships (pressure-resistant) contributed towards reducing corporate performance during the crisis.
\end{abstract}

Key words: Firm value, institutional directors, pressure-resistant directors, pressure-sensitive directors, board of directors

JEL: L25, M12, M14 


\section{INTRODUCTION}

Boards of directors can play a significant role in controlling agency problems. From an agency perspective, the ability of a board to monitor its managers depends on the directors' degree of independence (Beasley, 1996; Dechow et al., 1996). However, in EU countries, independent directors do not appear to be particularly efficient, and directors representing institutional investors sometimes play a more important role as board members (PuchetaMartínez and García-Meca, 2014). In this context, in contrast to the Anglo-Saxon environment, the control exercised by institutional investors who are also board members enables them to take part in the internal decision-making process of a firm (e.g., Hoshi et al., 1993; Pucheta-Martínez and García-Meca, 2014; Weinstein and Yafeh, 1998).

The presence of board members representing institutional investors is increasing throughout all OECD countries, and institutions are becoming more dominant in corporate governance, even in civil-law countries (Jara-Bertín et al., 2012). Prior research has not yet examined how directors representing institutional shareholders affect corporate performance in a low investor protection environment with a high presence of this type of board members, such as Spain. Therefore, our paper studies, firstly, how institutional directors affect company performance and, secondly, the influence on firm value of directors appointed by different institutional investors; specifically, and following López-Iturriaga et al. (2014), we distinguish between directors representing banks, savings banks and insurance companies and directors representing investment, mutual and pension funds. In accordance with previous literature (Almazán et al., 2005; Chen et al., 2007; Cornett et al., 2007), we differentiate between institutional investors who maintain business ties with the companies, defined as pressure-sensitive, and those who do not, defined as pressure-resistant.

Therefore, this paper has two main purposes. Firstly, we study the relationship between institutional directors and firm performance. Secondly, we distinguish between those 
directors that represent investors who maintain commercial links with the company where they serve as board members and those who do not, and we explore how they affect firm value. We focus on Spain due to its high number of this type of director on its boards, with institutional investors simultaneously being both core shareholders and highly represented directors.

This paper makes several different contributions. First, we show the effects of directors representing institutional investors on value creation in a way that is not possible to capture in those countries where institutional investors are only shareholders. Due to its institutional investors being simultaneously core shareholders and highly represented directors, Spain affords an exceptional occasion to explore how institutional directors are associated with corporate performance creation. Secondly, our estimates note that the negative effect of resistant institutional investors on firm performance was higher during the crisis, suggesting that the short horizon of resistant institutional investors led managers to adopt adverse short-term strategies affecting performance, especially during turbulent market periods.

These findings have implications for numerous parties, such as institutional investors, regulators, potential new board members and other corporate governance reform proponents, who frequently examine board characteristics to assess the effectiveness of boards in value creation policies by providing important policy implications for the design of corporate boards.

The findings show that institutional directors are negatively associated with firm value. Furthermore, our results also find that there are no differences between directors representing banks, saving banks and insurance companies, and directors representing investment, mutual and pension funds. The results also suggest that an emphasis on board independence alone may not be enough to enhance value creation since it does not impact on 
firm value. Instead, focusing on foreign directors may be a more fruitful way to increase performance, especially in countries with high ownership concentration. Our findings support this assertion. In addition, when we analyse the effect of institutional and foreign directors before and during the crisis, the findings show that only foreign directors affect firm value positively during both periods, while directors with no business relationships influence corporate performance negatively during the crisis.

In the next section, we describe the institutional context where the research was conducted. In the third section, we provide the hypotheses development. The fourth section offers the sample, variables and methodology. The fifth section analyses the results and, finally, the sixth section draws the most important conclusions.

\section{INSTITUTIONAL SETTING}

Spanish companies are characterized by a one-tier board system, high ownership concentration, low independence, and a high proportion of directors representing institutional investors on boards (Heidrick and Struggles, 2011).

In Spain, important institutions such as the state, large banks and recently privatized companies have become controlling shareholders and play important roles when solving important corporate governance issues (Crespí et al., 2004). These controlling shareholders usually sit on boards in order to represent the interests of institutional investors, playing an important role as controlling shareholders, members of their boards and creditors (e.g. banks). However, in the Anglo-Saxon context, capital markets play an important role as a funding source of companies, and directors representing institutional investors are not so important. Therefore, most of the institutional investors on Spanish boards belong to banks and also to investment funds. In addition, previous research conducted in Spain (García-Meca and Sánchez-Ballesta, 2009; Lorca et al., 2011; Pucheta-Martínez and García-Meca, 2014) reports 
that the effective monitoring of management is exercised by institutional board membership and not by independent directors, finding inconclusive results for the supervisory role of independent directors in comparison to institutional investors.

In order to increase the transparency of the stock markets and to protect the rights of shareholders, particularly minority shareholders, Spain carried out legal and institutional changes. Several Corporate Governance Codes were set in order to recommend compliance with corporate governance regulations. For example, the Olivencia Report (1998) established firm value for shareholders as the principal priority. In 2003, the Law on Transparency of Listed Firms (LTLF) Report and the Aldama Report (2003) were published. The Aldama Report, which replaced the Olivencia Report (1998), defined that all board members had to pursue the firm's sustainability in the long run. Finally, in 2006, the Unified Code of Corporate Governance (CUBG, 2006) Report, or Conthe Code, was published, which unified the Olivencia and Aldama Reports. The purpose of the CUBG (2006) was to improve business management and return transparency to the Spanish system. Three kinds of directors were distinguished by the CUGB (2006): executive, independent and institutional. While executive directors are insiders and are directly involved in the management of the firm, both independent and institutional directors are considered as outsiders with different agendas and incentives for controlling managers. The CUBG (2006) recommended that Spanish boards be made up mainly of outsiders. In other words, the presence of insiders had to be kept to the minimum possible level in order to address information and communications needs. The proportion of independent directors recommended was at least a third of the total number of board directors, since they represented the rights of the minority shareholders. 


\section{HYPOTHESES DEVELOPMENT}

The board of directors plays an important role in overseeing and monitoring the company, and its composition is crucial for reducing agency problems and aligning the motivations between principal and agent.

Previous literature analysing how institutional directors affect corporate value is heterogeneous. Some papers such as Kochhar and David (1996), Li and Shackell (2001) and Song et al. (2016), note that these directors are mainly concerned about maximizing the profits of their reference shareholders, noting a positive role of these directors. In this regard, some other papers suggest that institutional directors help managers to implement their strategies and facilitate coordination among stakeholders (Cuevas-Rodríguez et al., 2012; Pugliese et al., 2009).

Nevertheless, other authors (Varma, 2001) argue that institutional directors are passive and claim that their monitoring role is ineffectivedue to conflicts of interest with the company (Black, 1992; Kochhar and David, 1996), their relatively short-sighted goals (institutional investors focus on short-term corporate performance) (Bushee, 1998; Coffee, 1991), the freerider problem (Admati et al, 1994), or because they simply do not have the necessary skills (Taylor, 1990). Consistent with these views, Pound (1988) posits that institutional investors may align themselves with incumbent managers due to strategic alliances or previously existing relationships and that this leads to a decline in corporate performance. Hence, based on the above heterogeneous arguments, we posit that institutional directors may influence corporate performance either negative or positively. Thus, we pose the following unsigned hypothesis:

Hypothesis 1: Firm performance is affected by institutional directors 
According to differences in preferences and incentives to control corporate decisions, we can find different behaviours in directors representing institutional investors. For instance, some institutional investors prefer short-term trading profits, whereas others prefer to monitor companies and exert influence on managers (Elyasiani and Jia, 2010). Wang (2014) supports the view that institutional directors are not a homogeneous group, categorising them according to three aspects: investment strategy, investment duration and the block-holding level. The author finds that these three factors, individually and collectively, drive the heterogeneity of institutional investors in mitigating accruals management and are also their incentives when monitoring managers with regard to accruals management. Koh (2007) also classifies institutional investors into two categories, according to their investment horizon long-term or transient institutional investors - in order to analyse their impact on the earnings management strategies of firms. His research demonstrates that long-term institutional investors alleviate aggressive earnings management, while transient institutional directors do not. Accordingly, institutional shareholders have different attitudes towards CEO compensation, Corporate Social Responsibility, profitability, earnings management, R\&D investment decisions and spending, anti-takeover amendments and remuneration policy, among others (López-Iturriaga et al., 2014; Ullah and Jamali, 2010). According to their business objectives, we can distinguish between pressure-sensitive and pressure-resistant institutional directors (Dong and Ozkan, 2008; Kochhar and David, 1996; Pound, 1988).

Mutual and investment funds, pension funds and venture capital firms are considered in the literature as pressure-resistant institutional investors. They are freer than other shareholders due to their only maintaining an investment relationship, and not a business relationship, with the companies in which they invest (Wahba and Elsayed, 2014). In this vein, authors such as Sahu et al. (2014) and Wahba and Elsayed (2014) reported that firms with a higher corporate value have more pressure-resistant than pressure-sensitive directors 
serving ontheir boards. However, pressure-resistant directors may align with managers (Van Nuys, 1993) and support their decisions, such as to decrease firm performance, because these directors are representing investors who might have business ties with the firm in the future (for instance, if a firm becomes interested in choosing a mutual or pension fund provider for their employees). This thesis is supported by Woidthe (2002), who found a negative relationship between public pension funds and firm value. Thus, the above views suggest that pressure-resistant institutional directors may affect corporate performance either positively or negatively.

On the other hand, pressure-sensitive institutional directors have higher monitoring costs due to their interests in protecting their relationships with the firm. Therefore, when banks are creditors and shareholders in companies, controlling and strategic coalitions may arise, creating groups in order to extract private benefits. They may also go along with management decisions in order to avoid jeopardising their business relationships with the firm, and vote in favour of management recommendations (Brickley et al., 1988), creating expropriating alliances with controlling shareholders (Pinto, 2006). Some prior research finds a negative association between sensitive institutional board members and firm performance. For instance, Bhattacharya and Graham (2007) and Sahu et al. (2014), noted that pressuresensitive institutional investors on boards in Finland and India are negatively associated with firm performance. Similar conclusions were found by Khanna and Palepu (2000), Mohanty (2002), Sarkar and Sarkar (2000) and Wahba and Elsayed (2014), who demonstrate a negative association between bank shareholding and corporate performance.

In accordance with the above arguments, we propose the following two hypotheses:

Hypothesis 2a: Firm performance is positively or negatively affected by pressureresistant institutional directors 
Hypothesis 2b: Firm performance is negatively affected by pressure-sensitive institutional directors

\section{SAMPLE, VARIABLES AND METHODOLOGY}

\section{Sample}

Our sample is composed of 144 non-financial companies listed on the Spanish Stock Exchange from 2004 to 2010. Financial entities have been excluded from the sample because they comply with specific accounting rules and because the role of their boards is limited, given the strict control that financial regulatory bodies exert over them. The SABI database was used to collect company market value and financial data, while the corporate governance report disclosed annually by listed companies was used to gather corporate governance data.

An unbalanced panel data set of 600 firm-year observations was built. According to Arellano (2003), the findings provided by unbalanced panel data sets can be as accurate as those provided by balanced panel data sets.

\section{Variables}

We measure performance by using Tobin's Q ratio (Vafaei et al., 2015). Computations of Tobin's Q ratio seen in the literature today often use Chung and Pruitt's (1994) approximation, which equals [market value of firm's common stock + liquidating value of preferred stock + book value of debt] divided by the total assets (Jiang et al., 2015). According to Chung and Pruitt (1994), this way of measuring Tobin's Q ratio can be considered an accurate indicator in line with the correct measurement of Tobin's Q ratio proposed by Lindenberg and Stephen (1981) from a theoretical perspective. Prior research focused on corporate governance effectiveness, and particularly board effectiveness, was 
based on these indicators as a proxy for corporate value (e.g. Carter et al., 2010; Hart et al., 2015; Jackling and Johl, 2009).

Previous research analysing the relationship between corporate governance and firm performance was based on accounting measures (Return on Equity, Return on Assets and Return on Sales) and market measures (Tobin's Q ratio), with Tobin's Q ratio being the most frequently used. Financial accounting measures have often been criticised because: (1) they are subject to manipulation; (2) assets might be undervalued; or (3) alterations might be created (Mackey and Barney, 2013; Sánchez-Ballesta and García-Meca, 2007).

Contrary to accounting indicators, Tobin's Q ratio, a market indicator of company value, is based on the whole value that the market has assigned to the company, being mainly free from associations with asset assessments, present activities or even the company's past profitability. This assessment underlines what future earnings the company expects and, therefore, it can be considered as a valuable measure for representing present strategies and plans. Under the strong market assumption, any positive impacts of boards would be readily apparent to market participants and so reflected in the market capitalization of the firm (Fama, 1998). In our sensitive analysis, we will also use the market to book ratio, already used as a measure of performance by Adjaoud et al (2007) and de Andrés and Vallelado (2008).

We also employ several independent variables. The first independent variable used is denoted by INST and shows how many institutional directors, who represent institutional investors, sit on boards. In line with López-Iturriaga et al. (2014), we also consider the presence of pressure-sensitive directors (i.e. financial entities and insurance firms) and pressure-resistant directors on boards (i.e. mutual and investment funds), denoted by SENSIT and RESIST respectively. Board independence is also employed, showing the proportion of independent directors on boards and denoted by INDEP. 
Based on prior research, we have taken into account various control variables that might affect corporate performance. The proportion of foreign directors (FOREIGN) on boards is controlled. This variable has been calculated as the ratio between the total number of foreign directors on boards and the total number of directors on boards (Oxelheim and Randoy, 2003; Choi et al., 2007). Firm size has been labelled as SIZE and has been measured as the log of total firm's assets (Bachoo et al., 2013; Song, 2014). The leverage of the firm has also been controlled (LEV), and is measured as the quotient of debt and total assets (Erkens et al., 2012). We also control for ownership concentration (OWNER), CEO duality as a dummy variable,denoted by DUALITY (Barroso-Castro et al., 2015), and the age of the firm (AGE). A summary of the variables used and their calculations are provided in Table 1.

--Insert table 1 about here--

The following models will be estimated in order to test our hypotheses:

QTobin $_{i t}=\alpha+\beta_{1} \cdot$ Inst $_{i t}+\beta_{2} \cdot$ Indep $_{i t}+\beta_{3} \cdot$ Foreign $_{i t}+\beta_{4} \cdot$ Size $_{i t}+\beta_{5} \cdot$ Age $_{i t}+\beta_{6} \cdot$ Duality $_{i t}+$ $\beta_{7} \cdot$ Lev $_{i t}+\beta_{8} \cdot$ Owner $_{i t}+\mu_{i t}+\varepsilon_{i t} \quad$ (1) QTobin $_{i t}=\alpha+\beta_{1} \cdot$ Sensit $_{i t}+\beta_{2} \cdot$ Indep $_{i t}+\beta_{3} \cdot$ Foreign $_{i t}+\beta_{4} \cdot$ Size $_{i t}+\beta_{5} \cdot$ Age $_{i t}+$ $\beta_{6} \cdot$ Duality $_{i t}+\beta_{7} \cdot$ Lev $_{i t}+\beta_{8} \cdot$ Owner $_{i t}++\mu_{i t}+\varepsilon_{i t}$

QTobin $_{i t}=\alpha+\beta_{1} \cdot$ Resist $_{i t}+\beta_{2} \cdot$ Indep $_{i t}+\beta_{3} \cdot$ Foreign $_{i t}+\beta_{4} \cdot$ Size $_{i t}+\beta_{5} \cdot$ Age $_{i t}+$ $\beta_{6} \cdot$ Duality $_{i t}+\beta_{7} \cdot$ Lev $_{i t}+\beta_{8} \cdot$ Owner $_{i t}+\mu_{i t}+\varepsilon_{i t}$

where firm fixed and year fixed effects are represented by $\mu_{\text {it }}$ and the error by $\varepsilon_{\text {it. }}$ The fixed effects of the companies take into account unobservable and constant features of the companies that are potentially associated with corporate performance. 


\section{ANALYSIS OF RESULTS}

\section{Descriptive Statistics}

In Table 2, we provide the main descriptive statistics of the variables. The mean value of Tobin's Q ratio is 1.59 . Institutional directorsaccount for $21 \%$ of the representation, while pressure-sensitive and pressure-resistant directors represent, on average, $7.10 \%$ and $13.90 \%$, respectively. $15.97 \%$ of the sample firms do not have institutional directors. Consistent with Li et al. (2006), who demonstrated the worldwide propensity to increase the presence of institutional directors serving on boards, this study shows that the percentage of institutional directors on Spanish boardrooms increased from $19.60 \%$ in 2004 to $21.70 \%$ in 2010 . According to panel $\mathrm{B}$, around $73 \%$ of companies have at least one institutional director on board. Independent directors represent $30 \%$ of the board sample while foreign directors represent only $5 \%$. The proportion of leverage (LEV) represents $60.20 \%$ and the ownership concentration $30.10 \%$. The average age of companies is 46.83 years and the firm size is 13.67 ( $\log$ of total assets expressed in thousands of euros). Finally, duality represents $33 \%$ of the firm observations.

$$
\text { --Insert table } 2 \text { about here- }
$$

In Table 3 we show the correlation coefficients of all the variables. Except for the INST-RESIST combination (which do not interact in the regressions), the coefficients report low values and, consequently, multicollinearity should not be considered as a concern. To make sure, we have also calculated the vector inflation factors (VIF's). The values of the VIF's are below 3 and, therefore, our findings are not skewed by multicollinearity (Kutner et al., 2005).

$$
\text { --Insert table } 3 \text { about here- }
$$

An exploratory examination was performed. In order to do so, the sample was split up into two groups, based on the proportion of institutional directors on boards: organisations 
whose proportion of institutional directors is higher than the INST median comprise one group and companies whose proportion of institutional directors is lower than the INST median form the other group. The remaining variables (SENSIT, RESIST and INDEP) follow the same pattern. Thus, we perform an analysis of mean differences in order to examine whether firm value is different between both groups. Table 4 shows the results. Despite being inconclusive, the results show that institutional directors are connected with differences in corporate performance. Particularly, pressure-resistant and pressure-sensitive directors, who represent pressure-resistant and pressure-sensitive investors, respectively, have a negative impact on company value. Additionally, the insignificant effect of directors representing independent directors supports previous findings regarding the null effect of these directors on Spanish boards (e.g. García-Osma and Gill de Albornoz, 2007; Lorca et al., 2011). According to previous literature, the non-significant influence of independent directors may be due to a "real lack of independence" of these directors in Spain.

--Insert table 4 about here-

\section{Baseline Regression Results}

Table 5 provides the estimates for the first hypothesis with the baseline model. The findings reporting the impact on company value of institutional directors on boards are shown in column 1. According to these results, the percentage of institutional directors is negatively associated with firm value and, consequently, the first hypothesis (H1) cannot be rejected. Our findings support the thesis of the passive monitoring role that institutional directors play with respect to the management team, given that an active monitoring role performed in firms where they have invested can cause conflicts of interest to arise in current or future commercial alliances with the firm, due to the free-rider problem, short-sighted horizons or because they lack the necessary skills (Bushee, 1998; Taylor, 1990). 
--Insert table 5 about here--

In columns 2 and 3 of Table 5, we separate the different types of pressure-sensitive and pressure-resistant directors. Our results do not find a different role for sensitive representative directors than resistant representatives. The findings for resistant directors are negative and significant at 5\%, in line with the hypothesis H2a. Pressure-sensitive directors are also negatively associated with corporate value at $10 \%$, consistent with hypothesis $\mathrm{H} 2 \mathrm{~b}$. This evidence suggests that firm value is negatively driven by both types of directors. This result may be justified because directors who represent resistant investors are primarily oriented towards stock market-based measures of performance. As a result, they may be much more concerned about selling the shares of an underperforming company than about investing time and energy in instituting a process of corporate restructuring. Additionally, pressureresistant directors, appointed by investors who frequently do not maintain commercial links with the companies where they hold shares, may find that potential commercial ties with the firm arise in the future (e.g. the company might wish to choose a pension fund provider for its employees) and, consequently, this view may also support the thesis that they could cooperate with managers (Van Nuys, 1993). In this line, Woidtke (2002) reported that institutional investors, such as public pension funds, were negatively associated with corporate performance. Additionally, pressure-sensitive directors maintain both commercial and investment ties with firms and, consequently, will align with the interests of management in order to avoid jeopardising the business relationship.

The results were also confirmed for independent directors. As expected, board independence has no effect on corporate performance, perhaps because the directors' "real independence" is called into question. Findings are in line with previous research conducted in Spain (García-Meca and Sánchez-Ballesta, 2009; García-Osma and Gill de Albornoz, 2007; Lorca et al., 2011; Pucheta-Martínez and García-Meca, 2014) reporting that effective 
monitoring of management is exercised by institutional board membership and not by independent directors. Regarding the control variables, ownership concentration (OWNER) and firm size (SIZE) have a negative impact on company value in the three models. The remaining control variables are insignificant.

Endogeneity concerns between institutional directors (resistant and sensitive) and firm value have also been addressed. Thus, we wonder if institutional (sensitive and resistant) directors have a negative impact on company performanceor, to the contrary, companies with low company value attract institutional (sensitive and resistant) directors to their boards. Despite the greater likelihood that the causality runs from institutional (resistant and sensitive) directors to corporate value, it is also likely that firm performance may impact on board composition. This issue is approached by lagging all the independent variables (INST, SENSIT and RESIST), in line with Ozkan (2007), who defends that the lagging of explanatory variables may mitigate endogeneity concerns. In Table 6, we report the findings, which are in line with our main results, i.e. institutional directors (INST), and especially resistant directors (RESIST), are negatively and significantly related to firm performance $(\mathrm{p}<0.01)$

--Insert table 6 about here-

\section{Analysis Extension}

In the analysis extension, we split the sample according to the period of time. Then, we distinguish between the pre-crisis time period (2004-2007) and the crisis time period (2008-2010). This analysis is highly relevant, according to the results of Manconi et al. (2012), because institutional investors played a significant role in propagating the crisis. We assume that the short horizon of resistant institutional investors can force managers to adopt adverse short-term strategies that may impair future performance, especially during turbulent 
market periods. The results from Table 7 show that when we only consider the pre-crisis time period, the variables representing institutional directors (INST, RESIST and SENSIT) are not significant in all the different models. Concretely, institutional directors only affected corporate value from 2008 to 2010. These findings suggest that before the crisis these directors did not affect firm performance.

On the other hand, if we look at the crisis time period, we observe that institutional directors contributed towards reducing the value of the firm, and if we distinguish these directors according to whether they are sensitive or resistant, we see that the negative effect is again mainly driven by those directors appointed by resistant investors $(\mathrm{p}<0.01)$. Therefore, these results suggest that pressure-resistant institutional directors affect performance negatively because they overvalue short-term profits potential due to their myopic perspective. Our results confirm the findings provided by Malconi et al (2012), who also suggested that during the crisis time period the pressure to sell and to meet liquidity needs were less serious problems for sensitive investors than for resistant investors.

$$
\text { --Insert table } 7 \text { about here- }
$$

\section{Sensitivity Analysis}

In order to check the robustness of the baseline results, we ran models 1, 2 and 3 using the market to book ratio (MTB) (Shapiro and Li, 2016) as a dependent variable. As we see in Table 8 , the variable institutional directors INST is significant $(\mathrm{p}<0.01)$ as are directors appointed by resistant investors RESIST $(\mathrm{p}<0.01)$. However, the variable representing sensitive directors is no longer significant, as in the baseline model, and foreign directors increase the performance of the company $(p<0.01)$. Therefore, the results show that representatives of institutional investors have a negative impact on corporate performance, but 
when we consider pressure-resistant directors in particular then we observe no significant impact.

--Insert table 8 about here--

\section{CONCLUSIONS}

Prior research reports the importance of dominant institutional investors around the world. Nevertheless, there is scant evidence on institutional investors performing as directors. We hypothesise that the motivations of institutional directors to impact on company performance depend on the sort of business ties between the institutional investors they represent and the firms. The impact on firm value of pressure-sensitive directors, representatives of shareholders that maintain investment and commercial relationships with the firm, and pressure-resistant directors, representatives of shareholders that only maintain commercial ties with companies, is also explored.

Our paper shows that in contexts where investor protection is low and regulatory support weak, institutional directors serving on boards show a negative relationship with corporate performance. The findings report that pressure-sensitive institutional and pressureresistant institutional directors do not behave differently. Their main orientation to stock market-based measures of performance can justify these results and explain why directors with no business relationships may be much more likely to be concerned about selling the shares of an underperforming company than investing time and energy in instituting a process of restructuring the firm. Therefore, pressure-resistant institutional directors might align with the management team, or might become entrenched in order to attain total control of companies and obtain private benefits, thus impacting negatively on company performance. The results also suggest that an emphasis on board independence alone may not be enough to enhance value creation since this does not impact on firm value, confirming previous results 
regarding the lack of significance of these directors in Spain. The results are robust to alternative measures of value creation.

We also analyse whether the effect of institutional directors changed before and during the crisis. Our evidence demonstrates that during the crisis the negative effect of institutional investors only took place in the resistant group. These findings suggest that the short horizon of resistant institutional investors could lead managers to adopt adverse short-term strategies that impair performance, especially during turbulent market periods where liquidity problems of resistant investors were higher.

This paper offers significant academic and political implications since it shows empirical evidence of how the behaviour of institutional directors, appointed by institutional investors, affects corporate performance, in a setting different from the Anglo-Saxon one, where examining the role performed by these directors becomes more complicated, given their low presence on boards. The findings contribute to the academic literature by showing that institutional investors, when acting as directors on boards, may not perform an active monitoring role affecting firm performance. Moreover, our results note a negative effect of these directors, which was even higher during the financial crisis. Accordingly, researchers who examine the role played by institutional investors should consider not only institutional investors' shareholding, but also their involvement with other corporate governance mechanisms such as boards.

\section{CONFLICT OF INTEREST}

The authors declare that they have no conflict of interest. The authors acknowledge the financial support of the Spanish Ministry of Economy (Research Project ECO 2017-82259$\mathrm{R})$. 


\section{REFERENCES}

Adjaoud, F, Zeghal, D., Andaleeb, S., 2007. The effect of board's quality on performance: study of Canadian firms'. Corporate Governance: An International Review, 15, 623635.

Admati, A.R., Pleidererer, P., Zechner, J., 1994. Large shareholder activism, risk sharing and financial market equilibrium. Journal of Political Economy, 102, 1097-1130.

Aitken, B., Harrison, A., 1999. Do domestic firms benefit from direct foreign investment?. Evidence from Venezuela. The American Economic Review, 89(3), 605-617.

Almazán, A., Hartzell, J. C., Starks, L. T., 2005. Active institutional shareholders and costs of monitoring: Evidence from executive compensation. Financial Management, 34(4), 5 34.

Bachoo, K., Tan, R., Wilson, M., Wilson, M. 2013. Firm value and the quality of sustainability reporting in Australia. Australian Accounting Review, 23(1), 67-87.

Barbosa, N., Louri, H., 2005. Corporate performance: Does ownership matter? Comparison of foreign and domestic owned firms in Greece and Portugal. Review of Industrial Organization, 27, 73-102

Barroso-Castro, C., Villegas-Periñan, M.M. and Casillas-Bueno, J.C. 2015. How boards' internal and external social capital interact to affect firm performance. Strategic Organization, Forthcoming. DOI: 10.1177/1476127015604799

Beasley, M. 1996. An empirical analysis of the relation between the board of director composition and financial statement fraud. The Accounting Review, 71(4), 443-465.

Benfratello, L., Sembenelli, A. 2006. Foreign ownership and productivity: Is the direction of causality so obvious?. International Journal of Industrial Organization, 24, 733-751.

Bernard, A.B., Jensen, J.B., 2007. Firm structure, multinationals, and manufacturing plant deaths. The Review of Economics and Statistics, 89(2), 193-204. 
Bhattacharya, P. S., Graham, M., 2007. Institutional ownership and firm performance evidence from Finland?, Working Paper, School of Accounting, Economics and Finance, Faculty of Business and Law, Deaking University, Melbourne.

Black, B.S., 1992. Institutional investors and corporate governance. The case for institutional Voice. Journal of Applied Corporate Finance, 19-32.

Brickley, J., Lease, R., Smith, C., 1988. Ownership structure and voting antitakeover amendments. Journal of Financial Economics, 20, 267-292.

Bushee, B. J., 1998. The influence of institutional investors on myopic R\&D investment behavior. The Accounting Review, 73(3), 305-333.

Carter, D. A., Simkins, B. J., Simpson, W. G. 2003. Corporate governance, board diversity, and firm value. Financial Review, 38(1), 33-53.

Carter, D. A., D'Souza, F., Simkins, B. J., Simpson, W. G. 2010. The gender and ethnic diversity of US boards and board committees and firm financial performance. Corporate Governance: An International Review, 18(5), 396-414.

Chen, K., Elder, R., Hsieh, Y. 2007. Corporate governance and earnings management: The implications of corporate governance best practice principles for Taiwanese listed companies. Journal of Contemporary Accounting and Economics, 3, 73-105.

Choi, J., Park, S., Yoo, S. 2007. The value of outside directors. Evidence from corporate governance reform in Korea. Journal of Financial and Quantitative Analysis, 42, 941962.

Choi, H.M., Sul, W., Min, S.K., 2012. Foreign board membership and firm value in Korea. Management Decision, 50(2), 207-233.

Chung, K.H., Pruitt, S.W. 1994. A simple approximation of Tobin's Q ratio. Financial Management, 23(3), 70-74. 
Coffee, J.C. 1991. Liquidity versus control: The institutional investors as corporate monitor. Columbia Law Review, 91, 1277-1367.

Cornett, M.M., Marcus, A.J., Saunders, A., Tehranian, H., 2007. The impact of institutional ownership on corporate operating performance. Journal of Banking and Finance, 31: $1771-1794$.

Crespí, R., Garcia-Cestona, M.A., Salas, V., 2004. Governance mechanisms in Spanish Banks. Does Ownership matter?. Journal of Banking and Finance, 28, 2311-2330.

Cuevas-Rodríguez, G., Gomez-Mejia, L.R., Wiseman, R.M., 2012. Has agency theory run its course?: Making the theory more flexible to inform the management of reward systems. Corporate Governance: An International Review, 20 (6), 526-546.

De Andrés, P., Vallelado, E., 2008. Corporate governance in banking: The role of the board of directors. Journal of Banking and Finance, 32(12), 2570-2580

Dechow, P, Sloan, R., Sweeney, A., 1996. Causes and consequences of earnings manipulations: An analysis of firms subject to enforcement actions by the SEC. Contemporary Accounting Research, 13 (1), 1-36.

Dong, M.; Ozkan, A, 2008. Institutional investors and director pay: an empirical study of UK companies. Journal of Multinational Financial Management, 18(1), 16-29.

Elyasiani, E., Jia, J. 2010. Distribution of institutional ownership and corporate firm performance. Journal of Banking \& Finance, 34(3), 606-620.

Erhardt, N.L., Werbel, J.D., Shrader, C.B., 2003. Board of director diversity and firm financial performance. Corporate Governance: An International Review, 11(2), 102111.

Erkens, M. Hung, P. Matos, 2012. Corporate governance in the 2007 - 2008 financial crisis: evidence from financial institutions worldwide. Journal of Corporate Finance, 18 (2), 389-411 
Ezat, A., El-Masry, A., 2008. The impact of corporate governance on the timeliness of corporate internet reporting by Egyptian listed companies. Managerial Finance, 34(12), 848-867.

Fogel, K. S., Lee, K. K., Lee, W. Y., Palmberg, J., 2013. Foreign Direct Investors as Change Agents: The Swedish Firm Experience. Corporate Governance: An International Review, 21(6), 516-534.

García-Meca, E., García-Sánchez, I., Martínez-Ferrero, J., 2015. Board diversity and its effects on bank performance: an international analysis, Journal of Banking and Finance, 53, 202-214.

García-Meca, E., Sánchez-Ballesta, J.P. 2009. Corporate governance and earnings management: A meta-analysis. Corporate Governance: An International Review, 17, $594-610$.

García Osma, B., Gill de Albornoz, B., 2007. The effect of the board composition and its monitoring committees on earnings management: Evidence from Spain. Corporate Governance: An International Review, 15(6), 1413-1428.

Georg, H., Strobl, E., 2001. Multinational companies and productivity spill-overs: A metaanalysis, Economic Journal, 111(475), 723-739.

Gurbuz, A. O., Aybars, A., 2010. The impact of foreign ownership on firm performance, Evidence from an emerging market: Turkey. American Journal of Economics \& Business Administration, 2(4), 350-359.

Hart, T.A., David, P., Shao, F., Fox, C.J. and Westermann-Behaylo, M. 2015. An examination of the impact of executive compensation disparity on corporate social performance. Strategic Organization, 13(3), 200-223.

Heidrick, Struggles, 2011. Challenging board performance. European Report on corporate governance: Heidrick \& Struggles. 
Huang, R. D., Shiu, C-Y., 2009. Local effects of foreign ownership in an emerging financial market: Evidence from qualified foreign institutional investors in Taiwan, Financial Management, 38(3), 567.

Jackling, B., Johl, S., 2009. Board structure and firm performance: Evidence from India's top companies. Corporate Governance: An International Review, 17(4), 492-509.

Jara-Bertín, M., López-Iturriaga, F., López-de-Foronda, O., 2012. Does the influence of institutional investors depend on the institutional framework? An international analysis, Applied Economics, 44(3), 265-278.

Jiang, H., Habib, A., Gong, R. 2015. Business cycle and management earnings forecasts. Abacus, 51(2), 279-310.

Khanna, T., Palepu, K., 1999. Emerging market business groups, foreign investors, andcorporate governance. NBER Working Paper No. 6955, National Bureau of Economic Research, Cambridge, MA, February.

Khanna, T., Palepu, K., 2000, Is group affiliation profitable in emerging markets? An analysis of diversified Indian business groups, Journal of Finance, 55(2), 867-91.

Khawar, M., 2003. Productivity and foreign direct investment: Evidence from Mexico," Journal of Economic Studies, 30(1), 66-76.

Kim, 2011. The Effect of Board Structure on Firm Value: A Multiple Identification Strategies Approach Using Korean Data, working paper.

Kim, D.S., Eum, S.S., 2008. The relationship between corporate governance and foreign ownership for Korean firms. International Business Review, 12(4), 155-72.

Kim, W., Lyn, E., 1990. FDI theories and the performance of foreign multinationals operating in the US. Journal of International Business Studies, 21(1), 41-53.

Kochhar, R., David, P., 1996. Institutional investors and firm innovation: A test of competing hypotheses. Strategic Management Journal, 17(1), 73-84. 
Konings, J., 2001. The effects of foreign direct investment on domestic firm. Economics of Transition, 9(3), 619-633.

Kutner, M., Nachtsheim, C., Neter, J., Li, W., 2005. Applied Linear Statistical Models. McGraw-Hill.

Li, D., Moshirian, F., Pham, P. K., Zein, J., 2006. When financial institutions are large shareholders: The role of macro corporate governance environments. Journal of Finance, 61, 2975-3007.

Li, L., Shackell, M., 2001. The Implications of Long-Term Performance Plans and Institutional Ownership for Firms Research and Development (R\&D) Investments. Journal of Accounting, Auditing \& Finance, 16, 117-139,

Lindenberg, E. B., Stephen A. R., 1981. Tobin's Q Ratio and Industrial Organization. Journal of Business, 54, 1-32.

López-Iturriaga F, García-Meca, E., Tejerina-Gaite, F., 2014. Institutional directors and board compensation: Spanish evidence, Business Research Quarterly, in press.

Lorca, C., Sanchez-Ballesta, J., Garcia-Meca, E., 2011. Board effectiveness and cost of debt. Journal of Business Ethics, 100, 613-631.

Manconi, A.; Massa, M., Yasuda, A. 2012. The role of institutional investors in propagating the crisis of 2007-2008., Journal of Financial Economics, 104, 491-518.

Mishra, A., 2014. Foreign ownership and firm value, evidence from Australian firms, AsiaPacific Financial markets, 1, 67-96.

Mohanty, P., 2002. Institutional investors and corporate governance in India. NSE Research Study.

Muller-Kahle, M. I., 2012. The impact of dominant ownership: the case of Anglo-American firms. Journal of Management \& Governance, 1-19. 
Oxelheim, L., Randøy, T., 2003. The impact of foreign membership on firm value. Journal of Banking and Finance, 27(12), 2369-2392.

Ozkan, N. 2007. Do corporate governance mechanisms influence CEO compensation?. An empirical investigation of UK companies. Journal of Multinational Financial Management, 17(5), 349-364.

Park, K. S.; Lee, E. J., 2006. The role of foreign investors on the management and corporate governance of Korean companies. The Korean Journal of Money and Finance, 20(2), 73-113.

Phung, D.N., Le, T.P.V., 2013. Foreign ownership, capital structure and firm performance: Empirical evidence from Vietnamese listed firms. The IUP Journal of Corporate Governance, 12(2), 40-58.

Pinto, M., 2006. The role of institutional investor in the corporate governance. German Working Papers in Law and Economics. Available at http://www.bepress. com/cgi/viewcontent.cgi? article=1134\&context=gwp (accessed 23 March 2009).

Pound, J., 1988. Proxy contests and the efficiency of shareholder oversight. Journal of Financial Economics, 20, 237-265.

Pucheta-Martínez, M. C., García-Meca, E., 2014. Institutional investors on Boards and Audit Committees and their effects on financial reporting quality. Corporate Governance: An International Review, 22(4), 347-363.

Pugliese, A., Bezemer, P. J., Zattoni, A., Huse, M., van den Bosch, F. A. J., Volberda, H. W., 2009. Boards of directors' contribution to strategy: A literature review and research agenda. Corporate Governance: An International Review, 17(3), 292-306.

Romalis, J., 2011.The value of foreign ownership. Economic and Business Review for Central and South-Eastern Europe, 13(1/2), 107-118.

Ruigrok, W., Peck, S., Tacheva, S., 2007. Nationality and gender diversity on Swiss corporate boards. Corporate Governance: An International Review, 15(4), 546-557. 
Sahu, A.K., Vaswani, L.K., Chakraborty, A., 2014. Institutional investments in India:

A review of the literature. The IUP Journal of Corporate Governance, 13(2), 42-59.

Samaha, K., Dahawy, K., Hussainey, K., Stapleton, P., 2012. The extent of corporate governance disclosure and its determinants in a developing market: The case of Egypt. Advances in Accounting, 28(1), 168-178

Sánchez Ballesta, JP., García Meca, E., 2007. A meta-analytic vision of the effect of ownership structure on firm performance, Corporate Governance: An International Review, 15(5), 879-893.

Shapiro, D., Li, J. 2016. Understanding the "Enigma" of Chinese Firm Performance: Confucius and Beyond, Management and Organization Review, 12(2), 259-267.

Sarkar, J., Sarkar, S., 2000. Large shareholder activism in corporate governance in developing countries: evidence from India. International Review of Finance, 1 (3), 161-194.

Shin, H.H., Lee, S.C., Chang, J.J., 2004. Outside monitors and firm value. Korean Journal of Finance, 17(1), 41-72.

Smith, S.C., Beom-Cheol C., Vodopivec, M., 1997. Privatization Incidence, Ownership Forms, and Firm Performance: Evidence from Slovenia. Journal of Comparative Economics, 25(2), 158-179.

Spencer Stuart Index, 2014. Spencer Stuart index of the Spanish boards of directors. https://www.spencerstuart.com/research-and-insight/spain-board-index-2014

Song, S, 2014. Unfavorable market conditions, institutional and financial development, and exits of foreign subsidiaries. Journal of International Management, 20, 279-289.

Song, Y., Gianiodis, P.T., Li, Y. 2016. Institutional ownership and corporate philanthropic giving in an emerging economy, Management and Organization Review, 12(2), 357385.

Taylor, W., 1990. Can big owners make a difference?. Harvard Business Review, 30, 70-82. 
Ullah, S. and Jamali, D. 2010. Institutional investors and Corporate Social Responsibility: The role of Islamic financial institutions. International Review of Business Research Papers, 6(1), 619-630.

Vafei, A., Ahmed, K., Mather, P. 2015. Board diversity and financial performance in the top 500 Australian firms. Australian Accounting Review, 25(4), 413-427.

Van der Walt, N., Ingley, C., 2003. Board dynamics and the influence of professional background, gender and ethnic diversity of directors. Corporate Governance: An International Review, 11(3), 218-234.

Van Nuys, K., 1993. Corporate governance through the proxy process: Evidence from the 1989 Honeywell proxy solicitation. Journal of Financial Economics, 34, 101-132.

Varma, J., 2001. The role of institutional investors in equity financing and corporate monitoring. Journal of Business and Economics Studies, 7(1), 39-53.

Wahba, H., Elsayed, K., 2014. The effect of institutional investor type on the relationship between CEO duality and financial performance. International Journal of Business Governance and Ethics, 9(3), 221.

Wei, Z., Xie, F., Zhang, S., 2005. Ownership structure and firm value in China's privatized firms: 1991-2001. Journal of Financial and Quantitative Analysis, 40, 87-108.

Weinstein, D., Yishay, Y., 1998. On the costs of a bank-centered financial system: Evidence from the changing main bank relations in Japan. Journal of Finance, 53, 635-72.

Williams, K., O'Reilly, C.A., 1998. Demography and Diversity in Organizations, in Barry M. Staw, and Robert M. Sutton (ed.), Research in Organizational Behavior, 77-140.

Woidtke, T., 2002. Agents watching agents?. Evidence from pension fund ownership and firm value. Journal of Financial Economics, 63(1), 99-131. 
Xiao, S.S., Jeong, I., Moon, J.J., Chung, Ch. Ch., Chung, J., 2013. Internationalization and performance of firms in China: Moderating effects of governance structure and the degree of centralized control. Journal of International Management, 19, 118-137.

Table 1. Description and calculation of the variables

\begin{tabular}{ll}
\hline Variable & Description \\
\hline Q TOBIN & $\begin{array}{l}\text { The market value of common stock plus book value of } \\
\text { long term debt divided by book value of total assets. }\end{array}$ \\
\hline INST & $\begin{array}{l}\text { Measured by the number of institutional members on } \\
\text { boards over the total number of members on boards }\end{array}$ \\
\hline SENSIT & $\begin{array}{l}\text { Measured by the number of pressure-sensitive members } \\
\text { on boards over the total number of members on boards }\end{array}$ \\
\hline RESIST & $\begin{array}{l}\text { Measured by the number of pressure-resistant members } \\
\text { on boards over the total number of members on boards }\end{array}$ \\
\hline INDEP & $\begin{array}{l}\text { Measured by the number of independent members on } \\
\text { boards over the total number of members on boards }\end{array}$ \\
\hline FOREIGN & $\begin{array}{l}\text { Measured by the number of foreign directors on boards } \\
\text { over the total number of members on boards }\end{array}$ \\
\hline LEV & Measured by debt over total assets \\
\hline OWNER & The ownership concentration in the firm \\
\hline DUALITY & $\begin{array}{l}\text { Dummy variable: } 1 \text { if the CEO also serves as chair of the } \\
\text { board and } 0, \text { otherwise }\end{array}$ \\
\hline AGE & The age in years of the company \\
\hline SIZE & The log of total assets \\
\hline
\end{tabular}

Table 2. Descriptive statistics

Panel A. Continuous variables

\begin{tabular}{llllll}
\hline & Mean & Std. Dev & Q25 & Q50 & Q75 \\
\hline QTOBIN & 1.599 & 1.056 & 1.000 & 1.280 & 1.650 \\
INST & 0.210 & 0.191 & 0.000 & 0.180 & 0.310 \\
SENSIT & 0.071 & 0.109 & 0.000 & 0.000 & 0.130 \\
RESIST & 0.139 & 0.182 & 0.000 & 0.090 & 0.200 \\
INDEP & 0.306 & 0.188 & 0.200 & 0.300 & 0.430 \\
FOREIGN & 0.056 & 0.119 & 0.000 & 0.000 & 0.067 \\
LEV & 0.602 & 0.185 & 0.494 & 0.618 & 0.736 \\
OWNER & 0.301 & 0.257 & 0.101 & 0.248 & 0.481 \\
AGE & 46.83 & 28.346 & 24.000 & 40.000 & 66.000 \\
SIZE & 13.67 & 1.931 & 12.244 & 13.504 & 14.868 \\
\hline
\end{tabular}




\begin{tabular}{lllll}
\hline & $\mathbf{0}$ & $\mathbf{\%}(\mathbf{0})$ & $\mathbf{1}$ & $\mathbf{\%}(\mathbf{1})$ \\
\hline DUALITY & 402 & $67 \%$ & 198 & $33 \%$ \\
INST_D & 160 & $26.67 \%$ & 440 & $73.33 \%$ \\
SENSIT_D & 356 & $59.34 \%$ & 244 & $40.66 \%$ \\
RESIST_D & 264 & $40 \%$ & 336 & $56 \%$
\end{tabular}

Q TOBIN is the proxy used for measuring corporate performance; INST shows the percentage of institutional members on boards; SENSIT is the percentage of pressure-sensitive directors on boards; RESIST is the percentage of pressure-resistant directors on boards; INST_D; SENSIT_D and RESIS_D are the dummy variables of institutional, sensitive and resistant directors respectively. INDEP is the proportion of independent directors on boards; FOREIGN is the proportion of foreign directors on boards; LEV is measured by debt over total assets; OWNER is the ownership concentration in the firm; DUALITY is a dummy coded 1 if the CEO also serves as chair of the board and 0, otherwise; SIZE is the log of total assets and AGE of the firm is the age in years of the company. 
Table 3. Correlation Matrix

\begin{tabular}{|c|c|c|c|c|c|c|c|c|c|c|}
\hline & QTOBIN & INST & SENSIT & RESIST & FOREIGN & INDEP & LEV & OWNER & AGE & SIZE \\
\hline QTOBIN & 1 & & & & & & & & & \\
\hline INST & $-0.134^{* *}$ & 1 & & & & & & & & \\
\hline SENSIT & $-0.110^{* *}$ & $0.361^{* *}$ & 1 & & & & & & & \\
\hline RESIST & -0.074 & $0.830^{* *}$ & $-0.221^{* *}$ & 1 & & & & & & \\
\hline FOREIGN & $0.129^{* *}$ & 0.060 & $-0.090^{*}$ & $0.117^{* *}$ & 1 & & & & & \\
\hline INDEP & 0.002 & $-0.377^{* *}$ & -0.070 & $-0.352^{* *}$ & $-0.165^{* *}$ & 1 & & & & \\
\hline OWNER & -0.064 & -0.076 & 0.053 & $-0.111^{* *}$ & $0.321^{* *}$ & $-0.103^{*}$ & $0.100^{*}$ & 1 & & \\
\hline AGE & -0.005 & $0.162^{* *}$ & -0.026 & $0.184^{* *}$ & 0.041 & $-0.091^{*}$ & $0.147^{* *}$ & -0.021 & 1 & \\
\hline SIZE & $-0.104^{*}$ & $0.106^{* *}$ & $0.194^{* *}$ & -0.006 & $0.164^{* *}$ & $0.198^{* *}$ & $0.442^{* *}$ & $0.217^{* *}$ & $0.190^{* *}$ & 1 \\
\hline
\end{tabular}

Q TOBIN is the proxy used for measuring corporate performance; INST shows the percentage of institutional members on boards; SENSIT is the percentage of pressuresensitive on boards; RESIST is the percentage of pressure-resistant directors on boards; FOREIGN is the proportion of foreign directors on boards; INDEP is the proportion of independent directors on boards; LEV is measured by debt over total assets; OWNER is the ownership concentration in the firm; DUALITY is a dummy coded 1 if the $\mathrm{CEO}$ also serves as chair of the board and 0 , otherwise; SIZE is the log of total assets and AGE of the firm is the age in years of the company. ${ }^{\mathrm{p}}<0.1 ; * * \mathrm{p}<0.05$; $* * * \mathrm{p}<0.01$. 


\section{Table 4. Test of means comparison}

\begin{tabular}{llll}
\hline & \multicolumn{2}{l}{ QTOBIN } & \\
\cline { 2 - 4 } & $\begin{array}{l}\text { Under } \\
\text { median }\end{array}$ & $\begin{array}{l}\text { Over } \\
\text { median }\end{array}$ & $p$-value \\
\cline { 2 - 4 } INST & 1.679 & 1.416 & 0.002 \\
SENSIT & 1.622 & 1.458 & 0.047 \\
RESIST & 1.633 & 1.441 & 0.020 \\
INDEP & 1.590 & 1.525 & 0.441
\end{tabular}

Q TOBIN is the proxy used for measuring corporate performance; INST shows the percentage of institutional members on boards; SENSIT is the percentage of pressure-sensitive directors on boards; RESIST is the percentage of pressure-resistant directors on boards; INDEP is the proportion of independent directors on boards. $\mathrm{P}$-value is the significance. 
Table 5. Regression models

\begin{tabular}{|c|c|c|c|}
\hline & (1) & (2) & (3) \\
\hline INST & $\begin{array}{l}-0.787 * * * \\
(-3.227)\end{array}$ & & \\
\hline SENSIT & & $\begin{array}{l}-0.679 * \\
(-1.690)\end{array}$ & \\
\hline RESIST & & & $\begin{array}{l}-0.576^{* *} \\
(-2.262)\end{array}$ \\
\hline INDEP & $\begin{array}{l}-0.045 \\
(-0.176)\end{array}$ & $\begin{array}{l}0.227 \\
(0.958)\end{array}$ & $\begin{array}{l}0.101 \\
(0.408)\end{array}$ \\
\hline FOREIGN & $\begin{array}{l}1.723 * * * \\
(4.602)\end{array}$ & $\begin{array}{l}1.608 * * * \\
(4.207)\end{array}$ & $\begin{array}{l}1.813 * * * \\
(4.791)\end{array}$ \\
\hline LEV & $\begin{array}{l}0.051 \\
(0.203)\end{array}$ & $\begin{array}{l}-0.055 \\
(-0.218)\end{array}$ & $\begin{array}{l}0.093 \\
(0.368)\end{array}$ \\
\hline OWNER & $\begin{array}{l}-0.457 * * * \\
(-2.580)\end{array}$ & $\begin{array}{l}-0.347 * * \\
(-1.978)\end{array}$ & $\begin{array}{l}-0.439 * * \\
(-2.456)\end{array}$ \\
\hline DUALITY & $\begin{array}{l}-0.030 \\
(-0.338)\end{array}$ & $\begin{array}{l}-0.021 \\
(-0.238)\end{array}$ & $\begin{array}{l}-0.027 \\
(-0.309)\end{array}$ \\
\hline AGE & $\begin{array}{l}0.001 \\
(0.663)\end{array}$ & $\begin{array}{l}0.000 \\
(0.274)\end{array}$ & $\begin{array}{l}0.001 \\
(0.690)\end{array}$ \\
\hline SIZE & $\begin{array}{l}-0.050 * \\
(-1.938)\end{array}$ & $\begin{array}{l}-0.052 * \\
(-1.944)\end{array}$ & $\begin{array}{l}-0.065^{* *} \\
(-2.530)\end{array}$ \\
\hline Firm fix effects & Yes & Yes & Yes \\
\hline
\end{tabular}

Q TOBIN is the proxy used for measuring corporate performance; INST shows the percentage of institutional members on boards; SENSIT is the percentage of pressure-sensitive directors on boards; RESIST is the percentage of pressure-resistant directors on boards; INDEP is the proportion of independent directors on boards; FOREIGN is the proportion of foreign directors on boards; LEV is measured by debt over total assets; OWNER is the ownership concentration in the firm; DUALITY is a dummy coded 1 if the CEO also serves as chair of the board and 0, otherwise; SIZE is the log of total assets and AGE of the firm is the age in years of the company.

$* \mathrm{p}<0.1 ; * * \mathrm{p}<0.05 ; * * * \mathrm{p}<0.01$ 
Table 6. Estimates of the baseline models lagging the independent variables

\begin{tabular}{|c|c|c|c|}
\hline & (1) & (2) & (3) \\
\hline INST_1 & $\begin{array}{l}-0.795 * * * \\
(-3.179)\end{array}$ & & \\
\hline SENSIT_1 & & $\begin{array}{l}-0.707 \\
(-1.639)\end{array}$ & \\
\hline RESIST_1 & & & $\begin{array}{l}-0.695 * * * \\
(-2.648)\end{array}$ \\
\hline INDEP & $\begin{array}{l}-0.009 \\
(-0.033)\end{array}$ & $\begin{array}{l}0.283 \\
(1.101)\end{array}$ & $\begin{array}{l}0.094 \\
(0.361)\end{array}$ \\
\hline FOREIGN & $\begin{array}{l}1.331 * * * \\
(3.359)\end{array}$ & $\begin{array}{l}1.091 * * * \\
(2.628)\end{array}$ & $\begin{array}{l}1.425 * * * \\
(3.570)\end{array}$ \\
\hline LEV & $\begin{array}{l}0.109 \\
(0.413)\end{array}$ & $\begin{array}{l}0.037 \\
(0.133)\end{array}$ & $\begin{array}{l}0.185 \\
(0.696)\end{array}$ \\
\hline OWNER & $\begin{array}{l}-0.490 * * * \\
(-2.662)\end{array}$ & $\begin{array}{l}-0.422 * * \\
(-2.2385)\end{array}$ & $\begin{array}{l}-0.492 * * * \\
(-2.650)\end{array}$ \\
\hline DUALITY & $\begin{array}{l}-0.022 \\
(-0.236)\end{array}$ & $\begin{array}{l}-0.008 \\
-(0.089)\end{array}$ & $\begin{array}{l}-0.012 \\
(-0.132)\end{array}$ \\
\hline AGE & $\begin{array}{l}0.002 \\
(1.135)\end{array}$ & $\begin{array}{l}0.001 \\
(0.611)\end{array}$ & $\begin{array}{l}0.002 \\
(1.130)\end{array}$ \\
\hline SIZE & $\begin{array}{c}-0.045^{*} \\
(-1.656)\end{array}$ & $\begin{array}{l}0.074 * * * \\
(4.001)\end{array}$ & $\begin{array}{l}-0.060 * * \\
(-2.234)\end{array}$ \\
\hline Firm fix effects & Yes & Yes & Yes \\
\hline
\end{tabular}

Q TOBIN is the proxy used for measuring corporate performance; INST shows the percentage of institutional members on boards; SENSIT is the percentage of pressure-sensitive directors on boards; RESIST is the percentage of pressure-resistant directors on boards; INDEP is the proportion of independent directors on boards; FOREIGN is the proportion of foreign directors on boards; LEV is measured by debt over total assets; OWNER is the ownership concentration in the firm; DUALITY is a dummy coded 1 if the CEO also serves as chair of the board and 0, otherwise; SIZE is the log of total assets and AGE of the firm is the age in years of the company.

$* \mathrm{p}<0.1 ; * * \mathrm{p}<0.05 ; * * \mathrm{p}<0.01$ 
Table 7. Regression models and crisis effect

\begin{tabular}{|c|c|c|c|c|c|c|}
\hline & Before cri & & & Crisis & & \\
\hline & (1) & (2) & (3) & (1) & (2) & (3) \\
\hline \multirow[t]{2}{*}{ INST } & -0.497 & & & $-1.133 * * *$ & & \\
\hline & $(-1.361)$ & & & $(-3.698)$ & & \\
\hline \multirow[t]{2}{*}{ SENSIT } & & -0.757 & & & -0.615 & \\
\hline & & $(-1.290)$ & & & $(-1.173)$ & \\
\hline \multirow[t]{2}{*}{ RESIST } & & & -0.214 & & & $-1.001 * * *$ \\
\hline & & & $(-0.564)$ & & & $(-3.101)$ \\
\hline \multirow[t]{2}{*}{ INDEP } & 0.183 & 0.330 & 0.324 & -0.227 & 0.187 & -0.063 \\
\hline & $(0.501)$ & $(0.989)$ & $(0.912)$ & $(-0.662)$ & $(0.567)$ & $(-0.188)$ \\
\hline \multirow[t]{2}{*}{ FOREIGN } & $1.987 * * *$ & $1.863 * * *$ & $2.009 * * *$ & $1.579 * * *$ & $1.485 * * *$ & $1.757 * * *$ \\
\hline & $(3.337)$ & $(3.098)$ & $(3.346)$ & $(3.537)$ & $(3.184)$ & $(3.878)$ \\
\hline \multirow[t]{2}{*}{ LEV } & -0.287 & -0.385 & -0.274 & 0.358 & 0.227 & 0.434 \\
\hline & $(-0.737)$ & $(-0.977)$ & $(-0.697)$ & (1.174) & $(0.471)$ & $(1.398)$ \\
\hline \multirow[t]{2}{*}{ OWNER } & -0.374 & -0.306 & -0.346 & $-0.599 * * *$ & $-0.427 *$ & $-0.597 * *$ \\
\hline & $(-1.453)$ & $(-1.204)$ & $(-1.335)$ & $(-2.594)$ & $(-1.838)$ & $(-2.547)$ \\
\hline \multirow[t]{2}{*}{ DUALITY } & -0.151 & -0.149 & -0.149 & 0.116 & 0.137 & 0.117 \\
\hline & $(-1.172)$ & $(-1.159)$ & $(-1.153)$ & (1.007) & (1.163) & (1.006) \\
\hline \multirow[t]{2}{*}{ AGE } & -0.001 & 0.000 & -0.001 & $0.004^{*}$ & 0.003 & 0.004 \\
\hline & $(-0.466)$ & $(0.274)$ & $(-0.489)$ & $(1.861)$ & $(1.401)$ & $(1.902)$ \\
\hline SIZE & $-0.065^{*}$ & -0.512 & $-0.076^{* *}$ & -0.037 & -0.042 & $-0.056^{*}$ \\
\hline \multirow{2}{*}{ Firm fix effects } & $(-1.657)$ & $(-1.944)$ & $(-1.974)$ & $(-1.133)$ & $(-1.219)$ & $(-1.692)$ \\
\hline & Yes & Yes & Yes & Yes & Yes & Yes \\
\hline
\end{tabular}

Q TOBIN is the proxy used for measuring corporate performance; INST shows the percentage of institutional members on boards; SENSIT is the percentage of pressuresensitive directors on boards; RESIST is the percentage of pressure-resistant directors on boards; INDEP is the proportion of independent directors on boards; FOREIGN is the proportion of foreign directors on boards; LEV is measured by debt over total assets; OWNER is the ownership concentration in the firm; DUALITY is a dummy coded 1 if the CEO also serves as chair of the board and 0 , otherwise; SIZE is the log of total assets and AGE of the firm is the age in years of the company.* $<<0.1$; $*$ p $<0.05$; $* * * p<0.01$ 
Table 8. Sensitivity analysis

\begin{tabular}{llll}
\hline & $(1)$ & $(2)$ & $(3)$ \\
\hline INST & $-2.038^{* * *}$ & & \\
SENSIT & $(-2.746)$ & & \\
RESIST & & -0.874 & \\
& & $(-0.715)$ & $-1.852^{* *}$ \\
INDEP & & & $(-2.396)$ \\
& & & 0.095 \\
FOREIGN & -0.165 & 0.626 & $(0.126)$ \\
& $(-0.212)$ & $(0.867)$ & $4.420 * * *$ \\
LEV & $3.596^{* * *}$ & $3.968^{* * *}$ & $(3.849)$ \\
& $(3.731)$ & $(3.413)$ & $2.692^{* * *}$ \\
OWNER & $2.529 * * *$ & $2.238^{* * *}$ & $(3.494)$ \\
& $(3.319)$ & $(3.020)$ & $-1.169 * *$ \\
DUALITY & $-1.165^{* *}$ & $-0.895 *$ & $(-2.156)$ \\
& $(-2.162)$ & $(-1.676)$ & 0.183 \\
AGE & 0.180 & 0.203 & $(0.681)$ \\
& $(0.163)$ & $(0.753)$ & -0.001 \\
& -0.001 & -0.003 & $(-0.227)$ \\
& $(-0.013)$ & $(-0.592)$ & $-0.148^{*}$ \\
& -0.109 & -0.131 & $(-1.888)$ \\
& $(-1.380)$ & $(-1.596)$ & Yes \\
\hline
\end{tabular}

MTB is the proxy used for measuring corporate performance; INST shows the percentage of institutional members on boards; SENSIT is the percentage of pressure-sensitive directors on boards; RESIST is the percentage of pressure-resistant directors on boards; INDEP is the proportion of independent directors on boards; FOREIGN is the proportion of foreign directors on boards; LEV is measured by debt over total assets; OWNER is the ownership concentration in the firm; DUALITY is a dummy coded 1 if the CEO also serves as chair of the board and 0, otherwise; SIZE is the log of total assets and AGE of the firm is the age in years of the company.

$* \mathrm{p}<0.1 ; *$ * $<0.05 ; * * * \mathrm{p}<0.01$ 